\title{
PREVENTION OF ELECTROCARDIOGRAPHIC AND HISTOPATHOLOGIC ALTERATIONS IN THE MURINE MODEL OF CHAGAS' DISEASE BY PREINOCULATION OF AN ATTENUATED TRYPANOSOMA CRUZI STRAIN(1)
}

\author{
Carlos Alberto CUNEO (2), Emma MOLINA DE RASPI (2), Miguel Angel BASOMBRIO (2)
}

\begin{abstract}
SUMMARY
The effects of infection with Trypanosoma cruzi on the electrocardiographic tracings of mice were studied in 4 groups of animals: (1) normal; (2) infected with a pathogenic T. cruzi strain (TS COB); (3) immunized with 3 intraperitoneal inocula of $10^{6}$ attenuated T. cruzi epimastigotes (TCC) and (4) immunized-infected, which sequentially received the treatments of groups 3 and 2 . Infection and protection were confirmed by xenodiagnosis and histopathology. Isolated alterations such as extrasystolia, $1^{\text {st }}$ degree atrioventricular block, arrhythmia and ST elevation were observed in normal as well as infected mice. However, tracings taken repeatedly on each mouse over a 293 day period revealed a set of alterations which were more frequently seen in infected $(14 / 22)$ than in normal $(4 / 27)$ animals $(p=0.00048)$. These alterations consisted of supraventricular tachycardia, sinus bradycardia and persisting, first degree AV blocks, often associated to pacemaker changes. Inoculation of attenuated $\mathbf{T}$. cruzi (group 3 ) did not increase these alterations $(2 / 27$ mice) but significantly prevented their development after challenge with the pathogenic strain $(1 / 19$ versus $14 / 22$ mice, $p=0.000095$ ). Thus, preimmunization reduced not only parasitemia but also a pathogenic consequence of $\mathbf{T}$. cruzi infection. This evidence is relevant for immunoprevention studies against Chagas' disease.
\end{abstract}

KEY WORDS: Chagas' disease; Electrocardiogram; Histopathology; Heart; Immunization.

\section{INTRODUCTION}

Electrocardiographic (ECG) abnormalities, with or without accompanying clinical symptoms, are the most frequent finding in Chagas'disease ${ }^{6}$. Several animal models 1.12 .16 have been explored in order to reproduce these alterations. Mice should be more suitable than larger animals to bring ECG alterations into contex 1 with infection or immunity 10 Trypanosoma cruzi. Host-parasite interactions have been extensively explored in mice and these animals can economically be used in large numbers.

We have previously studied the immunization against chronic $\mathbf{T}$. cruzi infection in mice by parasitological, histopathological 3.4 and serological ${ }^{2}$ determinations. Moreover, our studies on the mouse ECG ${ }^{8}$ allowed us to characterize some $T$. cruzi-associated ECG alterations, particularly those related to atrioventricular conduction.

The purpose of this work was to depict the ECG alterations which distinguish normal from

(1) This investigation received financial support from CONICET (Consejo Nacional de Irvestigaciones Científicas y Técnicas), SECYT (Secretaría de Ciencia y Técnica) and Consejo de Investigación de la Universidad Nacional de Salta, Argentina.

(2) Laboratorio de Patología Experimental, Facultad de Ciencias de la Salud, Universidad Nacional de Salta, Calle Buenos Aires 177,4400 Salta, Argentina. 
CUNEO, C.A.; MOLINA DE RASPI, E. \& BASOMBRIO, M.A. - Prevention of electrocardiographic and histopathologic alterations in the murine model of Chagas' disease by preinoculation of an attenuated Trypanosoma cruzi strain. Rev. Inst. Med. trop. S. Paulo, 31(4):248-255, 1989.

chagasic tracings and to see whether such alterations can be prevented by immunization against $\mathbf{T}$. cruzi.

\section{MATERIAL AND METHODS}

Mice. Swiss male mice were used. They weighed $21 \pm 2 \mathrm{~g}$ at the beginning and $52 \pm 5 \mathrm{~g}$ at the end of the experiments. Hearts weighed at this time $230 \pm 61 \mathrm{mg}$.

Parasites. An attenuated and a virulent strain of T. cruzi were used for immunization and challenge respectively. The attenuated strain, named $\mathrm{TCC}^{2}$ has been kept in culture for more than 16 years. During this period, a progressive loss of in vivo infectivity along with adaptation to in vitro growth was detected. The parasites were subcultured every 2 weeks in glass bottles with biphasic, liver-heart infusion medium and antibiotics. Most parasites were in the epimastigote stage, with less than $10^{-3}$ trypomastigotes. No histopathologic lesions were detected after inoculation of these parasites in mice 2 .

The virulent isolate (TS COB) was obtained from one Triatoma infestans captured in a human dwelling in Cobos, Province of Salta, Argentina. This isolate induces typical lesions of Chagas'disease in at least the heart, muscle and urinary bladder of mice?

Xenodiagnosis. Groups of 10, third instar T. infestans were fasted for one month and then allowed to feed on each anesthesized experimental animal for 20 minutes in darkness. Thirty and sixty days later, a fresh mount of the pooled bug's feces diluted in culture medium was examined under the microscope in over $200,0.45 \mathrm{~mm}$ diameter fields.

Electrocardiograms. ECG tracings were taken from each mouse under sodium pentobarbital anesthesia $(50 \mathrm{mg} / \mathrm{Kg})$ at various times post challenge. Clip-type electrodes were connected to each limb after moistening the skin with $96 \%$ alcohol and $0.9 \% \mathrm{Na} \mathrm{Cl}$ solution. This provided electric contact and harmless immobilization of the animal. DI, DII, DIII, a VR, a VL, a VF, two precordial and one subxifoid lead tracings were recorded on a Fukuda Denshi electrocardiograph with paper speed set at $50 \mathrm{~mm} / \mathrm{sec}$ and amplitude at $20 \mathrm{~mm} / \mathrm{m} \mathrm{V}$.

Diagnostic criteria. Normal heart rate: $486 \pm$
83 beats per minute. Sinus bradycardia: sinus rhythm less than 403 beats per minute. First degree auriculo ventricular (A-V) block: heart rate multiplied by $\mathrm{PQ}$ interval exceeding 23.8 (see ref. 8). Supraventricular extrasystolia: premature beats with or without $P$ wave and normal QRS shape. Supraventricular tachycardia: three or more supraventricular premature contractions in a run.

Histopathology. The heart, urinary bladder and quadriceps muscle of each mouse were fixed in 10\% formaldehyde and histological, hematoxilin-eosin stained sections were studied. Quantitation of lesions was based on a double-blind analysis of 3 frontal sections of each organ, each taken at approximately $1 \mathrm{~mm}$ from each other. The degree of inflammatory mononuclear infiltration was classified as follows: 0 -- no lesions; 1 - tissues presenting a total of 1 to 4 foci of infiltration in all sections; 2 - more than 4 foci and 3 extensive or confluent areas of infiltration, often associated with degenerative or fibrotic lesions.

Experimental schedule. Four groups of mice were used. Group 1 ("normal") consist ed of 27 mice which only received injections of culture medium. Group 2 ("infected", 22 mice) received an intradermal inoculum of $0.05 \mathrm{ml}$ of T. infestans feces diluted in culture medium containing 10 TS COB trypomastigotes. Group 3 ("immunized", 22 mice) received 3 intraperitoneal injections of $10^{6}$ TCC parasites diluted in $0.1 \mathrm{ml}$ of culture medium at weekly interval. Group 4 ("immunized-infected", 19 mice) was treated sequentially as groups 3 and 2 .

Time schedules were as follows. Mice received the first immunizing inoculum when they were 2 months old and were challenged at 3 months of age (day 0). All animals were subjected to xenodiagnosis on days 27 and 336 and to ECG tracings on days 29,111,218 and 322. Autopsies and histopathological study were performed on day 377 on all animals, except for a few which were autopsied as they unexpectedly died during the study.

There was some variation in the number of mice per experimental group that were used for measurement of different parameters. This was due to animals lost during the experiment and to loss of a few samples of triatomae or tissues. 
CUNEO, C.A.; MOLINA DE RASPI, E. \& BASOMBRIO, M.A. - Prevention of electrocardiographic and histopathologic alterations in the murine model of Chagas' disease by preinoculation of an attenuated Trypanosoma cruzi strain. Rev. Inst. Med. trop. S. Paulo, 31(4):248-255, 1989.

\section{RESULTS}

\section{Xenodiagnosis}

All mice in the infected group had and active T. cruzi infection during the experiments, since either before (day 27) or after (day 336) ECG determination, the parasite was recovered from $100 \%$ of the animals by xenodiagnosis. Conversely, no parasites could be recovered by xenodiagnosis from mice inoculated with TCC alone (group 3).

Preinoculations with TCC produced a significant and lasting reduction in the level of parasitemia, as no parasites could be recovered from most mice in the immunized-infected group. Again, this reduction was detected both before (day 27) and after (day 336) the ECG determinations (Table 1).

TABLE 1

Recovery of $T$. cruzi by xenodiagnosis* from infected (group 2) and immunized-infected (group 4) mice

\begin{tabular}{cccc}
\hline Days post & \multicolumn{2}{c}{ Positive mice/ Total mice } & \multirow{2}{*}{$\mathrm{p}^{* *}$} \\
\cline { 2 - 3 } infection & $\begin{array}{c}\text { Immunized- } \\
\text { infected } \\
\text { mice }\end{array}$ & $\begin{array}{c}\text { Infected } \\
\text { mice }\end{array}$ & \\
\hline 27 & $4 / 15$ & $17 / 17$ & 0.0000105 \\
336 & $3 / 12$ & $16 / 16$ & 0.000032 \\
\hline
\end{tabular}

* Xenodiagnoses were always negative in mice inoculated with TCC alone (Group 3)

* * Calculated with Fisher's exact test.

\section{Histopathology}

Most mice in the infected group had alterations compatible with experimental Chagas'disease (Fig. 1). Hearts showed interstitial inflammatory infiltrates, often subendocardial, in the atrial wall. The ventricular tissue occasionally presented mononuclear infiltrates, predominating around valves and blood vessels. Localized areas of degenerating fibers were often accompanied by adjacent hypertrophic or peripherally located nuclei. Discrete areas of fibrosis were found in about half of the hearts studied.

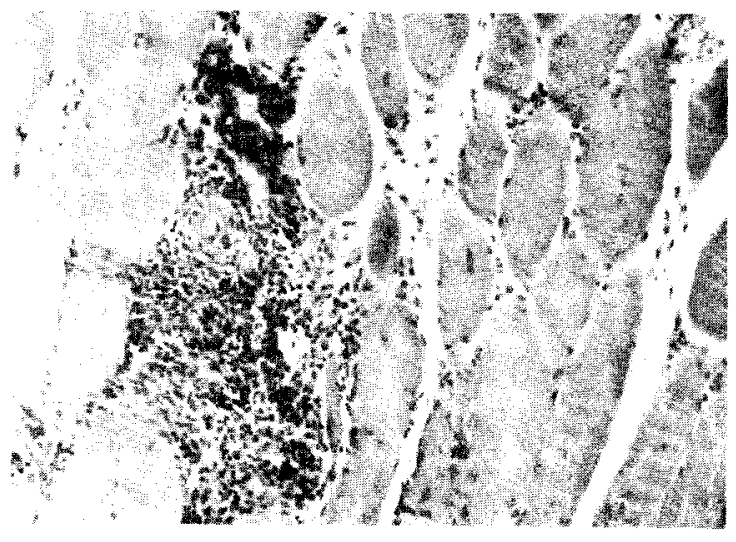

Fig. 1 - Hematoxylin-eosin stained section of mouse heart (base of ventricle), 377 days after T. cruzi infection. Note a dense lymphomonocytic infiltrate (left) and slight fibrosis between muscle fibers (right).

There was a sharp association between $\mathbf{T}$. cruzi infection and infiltrative heart lesions. Degenerative and fibrotic lesions, on the other hand, appeared to be a consequence of old age, as they were found in normal mice and most animals were autopsied on day 377 post infection.

Urinary bladders presented focal and perivascular mononuclear infiltrates. Skeletal muscle showed the same type of lesions, but they were more extense and severe, including fiber degeneration and fibrotic scars.

In contrast to the above findings, no histopathological alterations were found in mice of groups 1 (normal) or 3 (TCC alone).

The blind, semiquantitative evaluation of specimens revealed that in the immunizedinfected group the infiltrative lesions had been prevented, as compared to the infected group (Fig. 2). The differences were significant in heart $(\mathrm{p}<0.005)$, muscle $(\mathrm{p}<0.001)$ and urinary bladder $(\mathrm{p}<0.04)$.

\section{ECG tracings}

Some ECG alterations (listed in Table 2, top) were found as often in the infected as in the normal group and could not be associated with T. cruzi infection. These were observed in a small proportion of mice and disappeared in subsequent ECG tracings of the same animal. They included extrasystolia and pacemaker 
CUNEO, C.A.; MOLINA DE RASPI, E. \& BASOMBRIO, M.A. - Prevention of electrocardiographic and histopathologic alterations in the murine model of Chagas' disease by preinoculation of an attenuated Trypanosoma cruzi strain. Rev. Inst. Med. trop. S. Paulo, 31(4):248-255, 1989.

TABLE 2

Screening for ECG alterations associated with $T$. cruzi infection in anesthesized mice

\begin{tabular}{|c|c|c|c|c|c|c|c|c|c|c|}
\hline \multirow{2}{*}{ Type of alteration } & \multicolumn{5}{|c|}{ Number of alterations / Total ECG's } & \multicolumn{5}{|c|}{ Number of alterations / Total mice* } \\
\hline & Normal & $\%)$ & $\begin{array}{l}\text { T. cruzi } \\
\text { infected }\end{array}$ & $(\%)$ & $\mathrm{p}$ & Normal & $(\%)$ & $\begin{array}{l}\text { T. cruzi } \\
\text { intected }\end{array}$ & $(\%)$ & $\mathrm{p}$ \\
\hline $\begin{array}{l}\text { Supraventricular } \\
\text { extrasistolia }\end{array}$ & $3 / 100$ & (3) & $4 / 74$ & (5) & $>0.1$ & $3 / 27$ & (11) & $3 / 22$ & (14) & $>0.1$ \\
\hline Pacemaker changes & $5 / 100$ & (5) & $4 / 74$ & (5) & $>0.1$ & $4 / 27$ & (15) & $2 / 22$ & (9) & $>0.1$ \\
\hline AV block, $1^{\text {st }}$ degree & $8 / 100$ & (8) & $14 / 74$ & (19) & $<0.05$ & $5 / 27$ & (19) & $9 / 22$ & (41) & $=0.014$ \\
\hline Sinus bradycardia & $5 / 100$ & (5) & $10 / 74$ & (14) & $<0.05$ & $2 / 27$ & (7) & $4 / 22$ & $(18)$ & $<0.1$ \\
\hline $\begin{array}{l}\text { Supraventricular } \\
\text { tachycardia }\end{array}$ & $0 / 100$ & (0) & $3 / 74$ & (4) & $<0.05$ & $0 / 27$ & $(0)$ & $3 / 22$ & (14) & $=0.104$ \\
\hline $\begin{array}{l}\text { Total } \\
\frac{T . \text { cruzi-associated }}{\text { alterations }}\end{array}$ & $13 / 100$ & (13) & $20 * / 74$ & (27) & $<0.02$ & $5 * / 27$ & (19) & $14 * / 22$ & (64) & $=0.00136$ \\
\hline
\end{tabular}

* Because some animals or ECG tracings had more than one alteration, these have not been aggregated in totals.

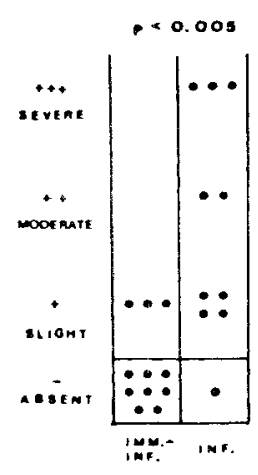

HEART

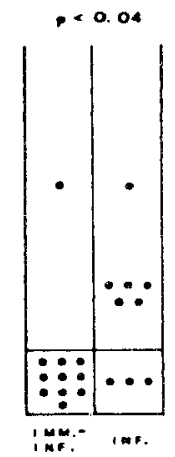

U. BLADOER

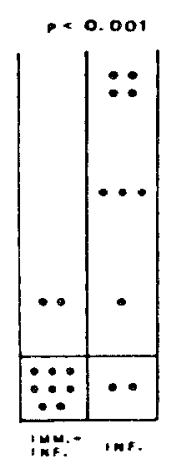

MUSCLE
Fig. 2 - Evaluation of tissue damage found in immunized infected (IMM-INF) and infected (INF) groups of mice, 377 days after $\mathbf{T}$. cruzi challenge. Lesions were classified blindly according to a predetermined score (See Materials and Methods). $p$ values were calculated with the Mann Whitney "U" test.

changes not associated to AV blocks. The level of the ST segment showed remarkable variation in normal mice.

Another set of alterations (Fig. 3 and Table 2 , bottom), consisting of 1 "degree AV blocks, supraventricular tachycardia and sinus bradycardia, was found significantly more often in infected (14/22) than in normal mice $(5 / 27, p$
$=0.00136$ ). The diagnosis of these alterations required their finding in the same mouse in 2 or more ocasions and they were considered to be associated with T. cruzi infection.

Inoculation of TCC alone (group 3) did not produce significant ECG changes as compared to controls (Table 3 ).

Preinoculations of TCC prevented T. cruzi-associated ECG alterations. These were as infrequent in the immunized or immunized-infected groups as in the normal group (Table 3 ).

\section{Relation between ECG alterations and heart histopathology}

Histopathological and electrocardiographic records of the same mouse were obtained in 30 cases from all experimental groups. Microscopic alterations were described as mononuclear infiltrates, hypertrophy and fibrosis. Both hypertrophy and fibrosis were found in normal animals and there was no association between these lesions and ECG alterations or T. ciuzi infections.

Miononuclear infiitrates, predominating in atria and perivalvular tissues were found exclusively in $\mathrm{i}$. cruzi infected mice. They were found in $78 \%$ of electrocardiographically abnormal mice and in only $29 \%$ of mice with normal ECG $(p=0.016$, see Table 4). 
CUNEO, C.A.; MOLINA DE RASPI, E. \& BASOMBRIO, M.A. - Prevention of electrocardiographic and histopathologic alterations in the murine model of Chagas' disease by preinoculation of an attenuated Trypanosoma cruzi strain. Rev. Inst. Med. trep. S. Paulo, 31(4):248-255, 1989.
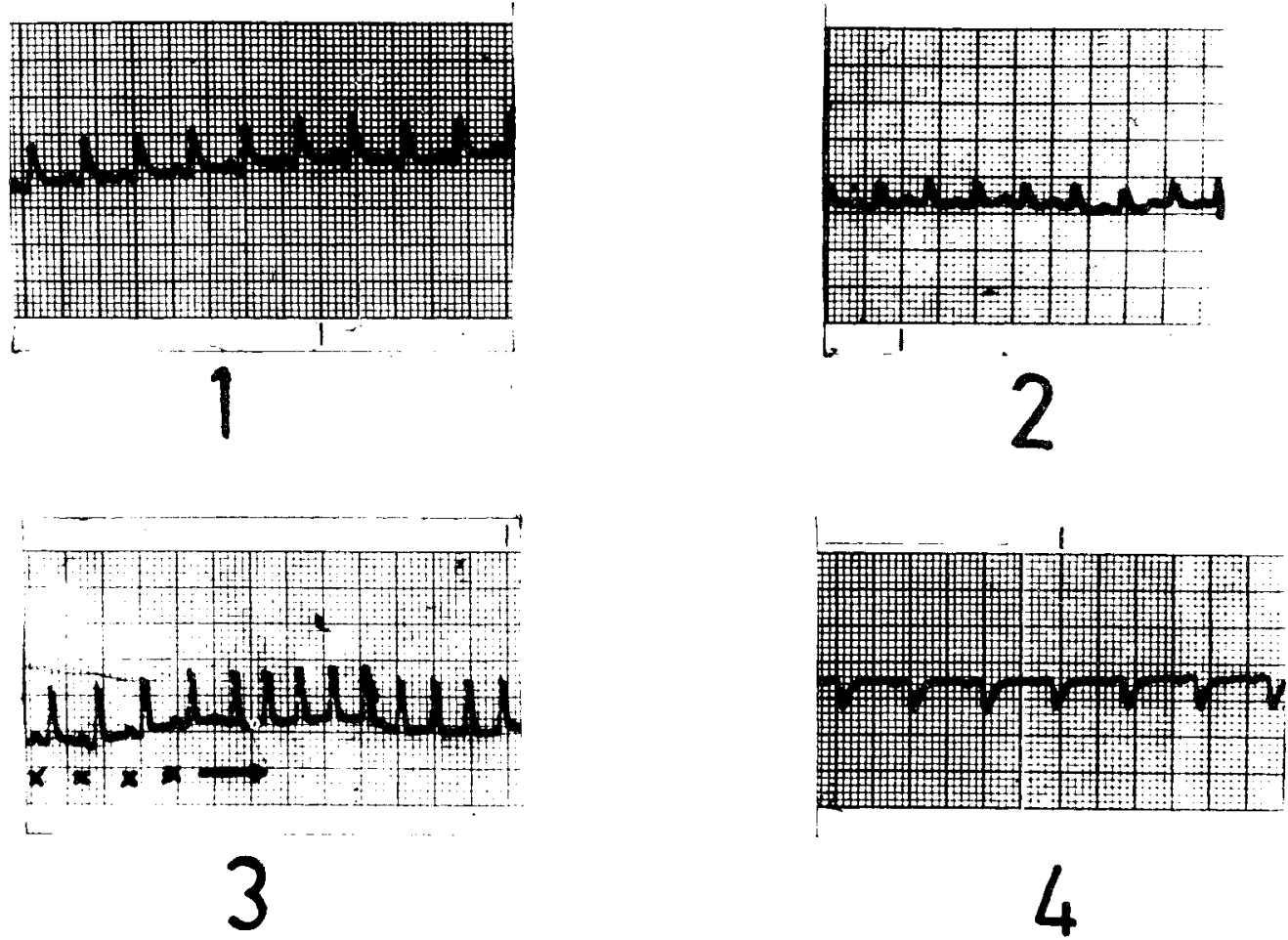

Fig. 3 - Electrocardiographic tracings of mice. 1: Normal D II tracing. 2: First degree AV block. Note prolonged PR interval as compared to 1. 3: Supravent ricular tachycardia. 4: Sinus bradycardia.

TABLE 3

Prevention of electrocardiographic alterations in $T$. cruzi infected mice by preinoculation of culture-attenuated parasites (TCC strain).

\begin{tabular}{|c|c|c|c|c|}
\hline \multirow{2}{*}{ Group } & \multirow{2}{*}{ Immunization } & \multirow{2}{*}{ Challenge } & ECG alterations* & \multirow{2}{*}{$\%$} \\
\hline & & & Total mice & \\
\hline 1 Normal & - & -. & $4 / 27$ & 15 \\
\hline 2 Infected & - & $10^{2}$ TS COB id** & $14 / 22$ & 64 \\
\hline 3 Immunized & $10^{6}$ TCC ip $\times 3$ & (n) & $2 / 22$ & 9 \\
\hline $\begin{array}{l}4 \text { Immunized- } \\
\text { infected }\end{array}$ & $10^{6}$ TCC ip $\times 3^{* * * *}$ & $10^{2} \mathrm{TSCOB}$ id & $1 / 19 * * * *$ & 5 \\
\hline
\end{tabular}

* Ii irst degree AV block, sinus bradycardia and supraventricular tachycardia.

** Intradermal.

*** Intraperitoneal.

**** Significant reduction as compared to group $2(p=0.000096)$ 
CUNEO, C.A.; MOLINA DE RASPI, E. \& BASOMBRIO, M.A. - Prevention of electrocardiographic and histopathologic alterations in the murine model of Chagas' disease by preinoculation of an attenuated Trypanosoma cruzi strain. Rev. Inst. Med. trop. S. Paulo, 31(4):248-255, 1989.

TABLE 4

Relationship between ECG alterations and heart histopathology in aged mice*

\begin{tabular}{|c|c|c|c|c|}
\hline & \multirow{2}{*}{$\begin{array}{l}\text { Total } \\
\text { mice }\end{array}$} & \multicolumn{3}{|c|}{$\begin{array}{c}\text { Mice with histopathological alterations in heart } \\
\text { number }-(\%)\end{array}$} \\
\hline & & Infiltration & Fibrosis & Hypertrophy \\
\hline $\begin{array}{l}\text { Mice with normal ECG or } \\
\text { non } T \text {. cruz } i \text { associated } \\
\text { alterations. }{ }^{* * *}\end{array}$ & 21 & $6(29)$ & $11(52)$ & $13(62)$ \\
\hline \multirow[t]{2}{*}{$\begin{array}{l}\text { Mice with } T \text {. cruzi asso- } \\
\text { ciated ECG alterations. } * *\end{array}$} & 9 & $7(78)$ & $6(67)$ & $7(78)$ \\
\hline & & $\mathrm{p}=0.016$ & $p=0.247$ & $p=0.243$ \\
\hline
\end{tabular}

* Most autopsies were performed 377 days after challenge.

** First degree AV block, sinus bradycardia and supraventricular tachycardia.

*** Including supraventricular extrasystolia, pacemaker changes and sinus tachycardia.

\section{DISCUSSION}

The data presented here show that characteristic ECG alterations can be found in a high proportion of mice after infection with $\mathbf{T}$. cruzi. Preimmunization of the animals with an attenuated $\mathbf{T}$. cruzi strain can prevent these alterations. Parasitological and histological findings on the same animals indicated the presence of chronic infection and disease (group 2) or immunological protection (group 4) during the 293 day period covered by this electrocardiographic study.

Electrical signals from the mouse heart have obviously not been as thoroughly interpreted as those from the human heart on account of the small size and high beat rate of this organ. The data so far available on prevalence and specificity of $\mathbf{T}$. cruzi-associated ECG alterations in mice differ among authors 5.11 .13 and may depend on mouse or parasite strains. There is, however, a general agreement that $T$. cruzi infected mice develop a spectrum of ECG changes 15 . On this ground, and following the recommendations derived from previous work ${ }^{15}$, we recorded ECG tracings of 9 derivations in each mouse, under the same anesthesia on 4 occasions during a 293 day period. Variables such as strain, age, sex and weight were controlled by using only Swiss male mice of the same age.

In previous work, second degree AV blocks or QRS widening were described among $T$. cruzi infected mices,11. We have not found these alterations in over $200 \mathrm{ECG}$ tracings from com- parable groups of animals. This is probably due to the T. cruzi isolate used in this work, which apparently causes a milder miocarditis. Conversely, first degree AV blocks, elevation of the ST segment, extrasystolia and pacemaker changes were previously considered as absent from normal mices,11, whereas we have detected these alterations in a small proportion of our uninfected controls. This discrepancy seems to arise from our study of each animal for long periods under standard pentobarbital anesthesia.

The variability found in the level of the ST segment seemed to be dependent on the QRS axis and apparently represented a normal repolarization pattern in the mouse. Moreover, the wide variations in heart rate exhibited by mice led us to introduce a correction factor $^{2}$ in the measurement of the PR interval. This increased the chances of detecting first degree AV blocks and was not previously taken into account.

The ECG alterations found by us were divided in two groups: non specific and $\mathbf{T}$. cruzi associated. Extrasystolia and pacemaker changes were distributed equally among normal and $\mathbf{T}$. cruzi infected mice and were classified as non specific. On the other hand, first degree AV blocks of long duration, sinus bradycardia and supraventricular tachycardia were found significantly more often among infected mice and thus taken as T. cruzi-associated. Hopely, as suggested by POSTAN et. al. 14 , the use of cloned $\mathbf{T}$. cruzi stocks and of inbred mice will increase the signal to noise ratio in this system.

The analysis of histopathologic and ECG data in the same mice shows that fibrosis may be 
CUNEO, C.A.; MOLINA DE RASPI, E. \& BASOMBRIO, M.A. - Prevention of electrocardiographic and histopathologic alterations in the murine model of Chagas' disease by preinoculation of an attenuated Trypanosoma cruzi strain. Rev. Inst. Med. trop. S. Paulo, 31(4):248-255, 1989.

found in aged, normal mice with no evident ECG alterations. The presence of inflammatory mononuclear infiltrates and possibly focal hyperthophy, are closely correlated with specific ECG changes such as 1 si degree AV block and supraventricular tachycardia.

In view of the numerous evidences for an autoimmune mechanism in $\mathbf{T}$. cruzi induced myocarditis ${ }^{1,7,9}$, it may seem paradoxical that immunization against the parasite in the mouse model prevents both histopathological and electrocardiographic manifestations of cardiopathy. It is increasingly evident that pathogenic or protective responses are the consequence of sensitizing the host with $\mathbf{T}$. cruzi antigens in two different ways: the first is represented by parasite fractions or partially purified antigens plus adjuvants. These can elicit heart specific autoantibodies, cytotoxic $\mathrm{T}$ lymphocytes, myocarditis and/or ECG alterations9,17,18. The second way is represented by live attenuated parasites or flagellar fractions. These do not seem to elicit pathological manifestations ${ }^{10,16}$ and, most important as shown here, they are preventable by a specified immunizing procedure.

The delineation of the antigenic specificities inducing either pathogenic or protective responses is necessary for understanding and eventually preventing heart disease in American Trypanosomiasis. Although these antigens have not been fully characterized so far, the possibility of producing the desired type of response in the mouse model, even by using crude or living immunogens as shown in this work, is a step forward toward that goal.

\section{RESUMO}

\section{Prevenção das alterações eletrocardiográficas e histopatológicas em modelo murino de doença de Chagas através da pré-inoculação de cepa atenuada de Trypanosoma cruzi}

Os efeitos da infecção do Trypanosoma cruzi nos traçados eletrocardiográficos de camundongos foram estudados em quatro grupos de animais: 1 . normal; 2 infectado com cepa patogênica de T. cruzi (TS .COB); 3. imunizados com três inoculações intra-peritoneais de $10^{6}$ epimastigotas de T. cruzi atenuadas (TCC) e 4. imunizados $\mathrm{e}$ infectados, que receberam seqüencialmente os tratamentos dos grupos 3 e 2 . A infecção e proteção foram confirmadas por xenodiagnóstico e histopatologia. Alterações isoladas tais como extrassistolia, bloqueio de primeiro grau átrio-ventricular, arritmia e elevação do ST foram observados tanto em camundongos normais como infectados. Entretanto, os traçados tomados de maneira repetida em cada camundongo durante um período de 293 dias revelaram conjunto de alterações que foram vistas mais freqüentemente em animais infectados $(14 / 22)$ que nos normais $(4 / 27)$ $(p=0.00048)$. Estas alterações consistiram de taquicardia supra-ventricular, bradicardia sinusal e bloqueios de primeiro grau AV, persistentes, freqüentemente associadas a alteraçôes do "pacemaker". A inoculação da cepa atenuada de T. cruzi (grupo 3) não aumentou estas alterações $(2 / 27)$ mas preveniu de maneira significante o seu desenvolvimento após o desafio com a cepa patogênica $(1 / 19$ versus $14 / 22$ camundongos, $\mathrm{p}=0.000095$ ). Portanto, a pré-imunização reduziu não somente a parasitemia mas a conseqüência patogênica da infecção pelo $\mathbf{T}$. cruzi. Esta evidência é relevante nos estudos de imunoprevenção em doença de Chagas.

\section{REFERENCES}

1. ACOSTA, A.A. \& SANTOS-BUCH, C.A. - Autoimmune myocarditis induced by Trypanosoma cruzi.Circulation, 71:1225-1261, 1985.

2. BASOMBRIO, M.A.; BESUSCHIO, S. \& COSSIO, P.M. - Side effects of immunization with live attenuated $\mathbf{T}$. cruzi in mice and rabbits. Infect. Immun., 36:342-350, 1982.

3. BASOMBRIO, M.A.; ARREDES, H.R.; ROSSI, R.A. \& MOLINA DE RASPI, E. - Histopathological and parasitological evidence of immunization of mice against challenge with 17 isolates of Trypanosoma cruzi. Int. J. Parasit., 16:375-380, 1986.

4. BASOMBRIO, M.A. \& BESUSCHIO, S. - Trypanosoma cruzi culture used as vaccine to prevent chronic Chagas'disease in mice. Infect. Immun., 36:351-356, 1982.

5. BIJOVKY, A.T.; ELIZARI, M.V.; MULLER, L.A.; KATZIN, V. \& GONZALEZ CAPPA, S.M. - Chronic infection of mice with Trypanosoma cruzi. Rev. Inst. Med. trop. S. Paulo, 25:207-214, 1983.

6. CORREA DE ARAUJO, R.; BESTETTI, R.B.; GODOY, R. \& OLIVEIRA, S.M. - Chronic Chagas heart disease in children and adolescents: a clinicopathologic study. Int. J. Cardiol., 9:439-449, 1985.

7. COSSIO, P.M.; DIEZ, C.; LAGUENS, R.P. \& ARANA, R. - Inmunopatologia de la enfermedad de Chagas. Hechos y perspectivas. Medicina (B. Aires), 40 (Suppl. 1):222-230, 1980.

8. CUNEO, C.A.; ARAOZ, G. \& BASOMBRIO, M.A. - Análisis de la conducción aurículoventricular en el eletrocardiograma del ratón normal. Medicina (B. Aires), 45:314-315, 1985. 
CUNEO, C.A.; MOLINA DE RASPI, E. \& BASOMBRIO, M.A. - Prevention of electrocardiographic and histopathologic alterations in the murine model of Chagas' disease by preinoculation of an attenuated Trypanosoma cruzi strain. Rev. Inst. Med. trop. S. Paulo, 31(4):248-255, 1989.

9. HUDSON, L. \& BRITTEN, V. - Immune response to South American trypanosomiasis and its relationship to Chagas'disease. Brit. med. Bull., 41:175-180, 1985.

10. LAGUENS, R.P.; CABEZA MECKERT, P.; ESTEVA, M.; CAMPANINI, A.R.; GELPI, R.; SUBLAS, E.; DEL PRADO, C.E. \& SEGURA, E.L. - Acción de las fracciones subcelulares de Trypanosoma cruzi sobre la enfermedad de Chagas crónica del ratón. II. Efecto sobre la evolución de la infección. Medicina (B. Aires), 40:807-808, 1980 (Abstract).

11. LAGUENS, R.P.; CABEZA MECKERT, P. \& GELPI, R.J. - Enfermedad de Chagas crónica en el ratón. I. Estudios electrocardiográficos y morfológicos del corazón. Medicina (B. Aires) 40:35-40, 1981.

12. MENEZES, H. - Active immunization of dogs with a non virulent strain of Trypanosoma cruzi. Rev. Inst. Med. trop. S. Paulo, 11:258-263, 1969.

13. MILEI, J.; MORALES, C.; BOLOMO, N.J.; BASOMBRIO, M.A. \& COSSIO, P.M. - Correlación electrocardiográfica-anatomopatológica en la miocardiopatía chagásica crónica en el ratón. Medicina (B. Aires), 42:925-926, 1982 (Abstract).

14.POSTAN, M.; DVORAK, J.A. \& MC DANIEL, J.P. - Studies on Trypanosoma cruzi clones in inbred mice. A comparison of the course of infection of $\mathrm{C} 3 \mathrm{H}=$
HEN mice with two clones isolated from a commom source. Amer. J. trop. Med. Hyg., 32:497-506, 1983.

15. Report of the scientific working group on the development and evaluation of animal models for Chagas'disease. World Health Organization. TDR programme. Geneva, p.4, 1984.

16. REVELLI, S.; AMERIO, N.; MORENO, H.S.; VALENTI, J.L.; BALBARREY, H. \& MORINI, J.C. Enfermedad de Chagas crónica en la rata. Caracteristicas serológicas, eletrocardiográficas e histopatológicas. Medicina (B. Aires), 40 (Suppl. 1):67-69, 1980.

17. SEGURA, E.L.; CABEZA MECKERT, P.; ESTEVA, M.; GELPI, R.; CAMPANINI, A.R.; SUBIAS, E. \& LAGUENS, R.P. - Acción de las fracciones subcelulares de Trypanosoma cruzi sobre la enfermedad de Chagas crónica del ratón. I. Inducción de cardiopatia en ausencia de infección. Medicina (B. Aires), 40:807, 1980 (Abstract)

18. TEIXEIRA, A.R.L.; TEIXEIRA, M.L. \& SANTOS BUCH, C.A. - The Immunology of experimental Chagas'disease. IV. Production of lesions in rabbits similar to those of chronic Chagas'disease in man. Amer. J. Path., 80:163-180, 1975.

Recebido para publicação em 22/4/1988. 